\title{
Dynamic Response of Asphalt Pavement in Tunnel Entrance and Exit Area Based on Mixture Viscoelasticity
}

\author{
Xueying Zhao ${ }^{1, *}$, Aiqin Shen ${ }^{1}$ and Cuizhen Xue ${ }^{1}$ \\ ${ }^{1}$ Key Laboratory of Highway Engineering in Special Region of Ministry of Education, Chang'an University, Xi'an, Shaanxi, China
}

\begin{abstract}
To further investigate the variation of stress under moving traffic loads in tunnel entrance and exit area, in this paper, a 3-D finite model(FE) of the pavement structure in entrance and exit section was established. The pavement of the tunnel consists of asphalt concrete and cement concrete. The viscoelastic property of asphalt mixture and the damping effect of the structure were considered. Dynamic traffic loads was applied during simulation. It is shown that the maximum interlayer shear stress between AC and PCC in the entrance and exit area of the tunnel was $28.37 \%$ larger than that of the regular pavement in the tunnel, which may be caused by the low cohesion between AC and PCC layers in the entrance and exit area of the tunnel.
\end{abstract}

\section{Introduction}

Great achievements have been made on highway construction in China, but pavement distress e.g. rutting, fatigue cracking, water damage, etc. appear in some sections within the design life, especially in special sections, such as polishing and traffic accidents in the entrance and exit section of freeway tunnel. Taking Niuwangshan tunnel in Jincheng-Yangcheng freeway ${ }^{[3]}$ as a typical example, only 18 months after opening, the pavement texture depth decreased from $0.72 \mathrm{~mm}$ to less than $0.2 \mathrm{~mm}$, and accordingly the number of traffic accidents in this section rose dramatically, accounting for about $50 \%$ of the total accidents in the whole line.

Taking into account this situation, researchers have already made great efforts. Fang Jing et al, established operating speed models for trucks at freeway tunnel sections and analyze the characteristics of driving behaviors through car following tests ${ }^{[2]}$. Li Yingtao analyzed working conditions of tunnel pavement, compared the performance between cement concrete pavement and asphalt concrete pavement in the tunnel and found that asphalt concrete pavement was preferred in tunnel pavement selection ${ }^{[3]}$; Gao Jing also analyzed working conditions of tunnel pavement and suggested that composite pavement should be taken precedence in the entrance and exit section for its comfort, anti-slide and convenient to repair ${ }^{[1]}$.

In previous, there are not many studies on the stress response under moving loads in entrance and exit section. In this paper, based on Jinan-Dongying freeway, three critical stress indexes(shear stress between AC and PCC in pavement of the tunnel $\tau_{\mathrm{AC}-\mathrm{PCC}}$, interlayer shear stress between SMA-13 and AC-16 $\tau_{\text {SMA-AC }}$, AC-16 and AC$20 \mathrm{C} \tau_{\mathrm{AC}-\mathrm{AC}}$ in main line pavement) are chosen, calculated and analyzed under moving loads, considering of viscoelastic property of asphalt mixture and the damping effect of the structure through ANSYS FE program.

\section{Dynamics Basic Theory}

According to Hamilton's Principle, pavement dynamics finite element equation is as follows:

$$
\mathrm{Mu}+\mathrm{Cu}+\mathrm{Ku}=\mathrm{F}(t)
$$

Where: $\mathrm{M}$ is the pavement mass matrix; $\mathrm{C}$ is the pavement damping matrix; $\mathrm{K}$ is the pavement stiffness matrix; $\mathrm{F}(\mathrm{t})$ is the loading function; $\mathrm{u}, \mathrm{u}, \mathrm{u}$ are node displacement, velocity and acceleration respectively.

Rayleigh damping assumptions was used to calculate damping matrix:

$$
\mathrm{C}=\alpha \mathrm{M}+\beta \mathrm{K}
$$

Where: $\alpha$ and $\beta$ are damping coefficient, and in this analysis, their simplified forms were used:

$$
\alpha=2 \lambda 1 \omega 1, \beta=2 \lambda 1 / \omega 1
$$

where: $\omega 1$ is the natural circular frequency; $\lambda 1$ is modal damping ratios.

\section{Viscoelastic parameters of asphalt mixture}

To characterize the mechanical property of asphalt mixture, the Burgers model has been used in this paper, which is illustrated in Figure 1 and given in Equation 4.

$$
\boldsymbol{\sigma}+\mathrm{p}_{1} \dot{\boldsymbol{\sigma}}+\mathrm{p}_{2} \ddot{\boldsymbol{\sigma}}=\mathrm{q}_{1} \dot{\varepsilon}+\mathrm{q}_{2} \ddot{\varepsilon}
$$

Where: $\mathrm{p}_{1}=\frac{\eta_{1}}{\mathrm{E}_{1}}+\frac{\eta_{2}}{\mathrm{E}_{2}}+\frac{\eta_{1}}{\mathrm{E}_{2}}, \mathrm{q}_{1}=\eta_{1}$

$$
\mathrm{p}_{2}=\frac{\eta_{1} \eta_{2}}{\mathrm{E}_{1} \mathrm{E}_{2}}, \quad \mathrm{q}_{2}=\frac{\eta_{1} \eta_{2}}{\mathrm{E}_{2}}
$$

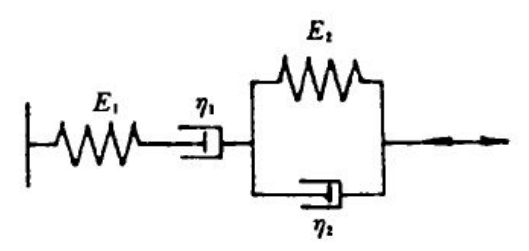

Figure 1. Burgers Model

Through Laplace transform method, shear relaxation modulus $G(t)$ could be solved as:

$$
\mathrm{G}(t)=\frac{1}{q_{0}}\left[\left(\eta_{1}-\beta E_{1} p_{2}\right) e^{-\beta t}-\left(\eta_{1}-\alpha E_{1} p_{2}\right) e^{-\alpha . t}\right]
$$

Whereq ${ }_{0}, \alpha$ and $\beta$ are parameters related to $E_{1}, E_{2}, \eta_{1}$ and $\eta_{2}$ and thus shear relaxation modulus were transformed to Prony series as shown in equation 7 . The material 
constants $E_{1}, E_{2}, \eta_{1}$ and $\eta_{2}$ were obtained from Reference[8].

$$
\mathrm{G}(t)=\mathrm{G}_{\infty}+\mathrm{G}_{0}\left(\mathrm{~g}_{1} \mathrm{e}^{-\frac{t}{t_{1}}}+\mathrm{g}_{2} \mathrm{e}^{-\frac{t}{t z}}\right)
$$

Where $\mathrm{G}_{\infty}=0, \mathrm{G}_{0}, \mathrm{~g}_{1}, \mathrm{~g}_{2}, \mathrm{t}_{1}, \mathrm{t}_{2}$ are constants related to $\mathrm{E}_{1}$, $\mathrm{E}_{2}, \eta_{1}$ and $\eta_{2}$.

\section{Pavement Structure and FE Model}

\subsection{Pavement Structure}

Based on the structure of main line of Jinan-Dongying Freeway and other studies ${ }^{[1,5]}$, the proposed pavement structure of entrance and exit section and geomaterial are shown in Table 1and Table 2.

Table 1. Drafted pavement structure of main mine section

\begin{tabular}{|c|c|c|c|}
\hline Course & $\begin{array}{c}\text { Depth } \\
\mathrm{h}(\mathrm{cm})\end{array}$ & $\begin{array}{c}\text { Dynamic } \\
\text { Modulus } \\
\mathrm{E}(\mathrm{MPa})\end{array}$ & $\begin{array}{c}\text { Poisson's } \\
\text { ratio } \\
\mu\end{array}$ \\
\hline SMA-13 & 4 & 7000 & 0.35 \\
\hline AC-16 & 5 & 9500 & 0.3 \\
\hline AC-20C & 6 & 9000 & 0.3 \\
\hline LSPM-30 & 12 & 7000 & 0.3 \\
\hline $\begin{array}{c}\text { cement stabilized } \\
\text { macadam }\end{array}$ & 36 & 1600 & 0.2 \\
\hline $\begin{array}{c}\text { lime and fly ash } \\
\text { stabilized soil }\end{array}$ & 18 & 800 & 0.2 \\
\hline subgrade & --- & 35 & 0.35 \\
\hline
\end{tabular}

Table 2. Drafted pavement structure of tunnel

\begin{tabular}{|c|c|c|c|c|}
\hline Course & $\begin{array}{c}\text { Depth } \\
\mathrm{h}(\mathrm{cm})\end{array}$ & $\begin{array}{c}\text { Dynamic } \\
\text { Modulus } \\
\mathrm{E}(\mathrm{MPa})\end{array}$ & $\begin{array}{c}\text { Elastic } \\
\text { Modulus } \\
\mathrm{E}(\mathrm{MPa})\end{array}$ & $\begin{array}{c}\text { Poisson's } \\
\text { ratio } \\
\mu\end{array}$ \\
\hline SMA-13 & 4 & 7000 & --- & 0.35 \\
\hline AC-16 & 5 & 9500 & --- & 0.3 \\
\hline $\begin{array}{c}\text { C40 cement } \\
\text { concrete board }\end{array}$ & 24 & --- & 40000 & 0.15 \\
\hline $\begin{array}{c}\text { C15 invert } \\
\text { cement } \\
\text { concrete }\end{array}$ & --- & --- & 15000 & 0.15 \\
\hline bedrock & --- & --- & 60000 & 0.15 \\
\hline
\end{tabular}

\subsection{The FE model}

Loads were applied at three different positions respectively: (a) pavement in entrance and exit area of the main line; (b) junction pavement in entrance and exit area; (c) pavement in entrance and exit area in the tunnel to simulate the process of entering and leaving a tunnel. Three corresponding finite element models were established respectively and shown in Figure 2, Figure 3 and Figure 4.
The $\operatorname{size}(x, y, z)$ was $4 \mathrm{~m} \times 5 \mathrm{~m} \times 10 \mathrm{~m}$. The $\mathrm{x}$-axis was on the pavement transverse direction and the $\mathrm{z}$-axis was on the advancing direction. To simplify the grounding shape of tires, it was assumed that the grounding shape was rectangle $(18 \mathrm{~cm} \times 20 \mathrm{~cm})$ and the distance between the center of two tires was $30 \mathrm{~cm}^{[4]}$.

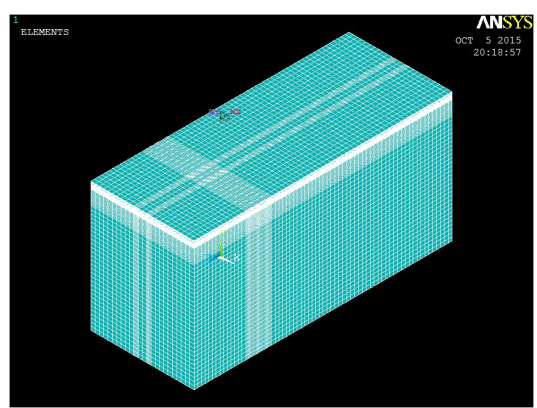

Figure 2. pavement in entrance and exit area of the main line

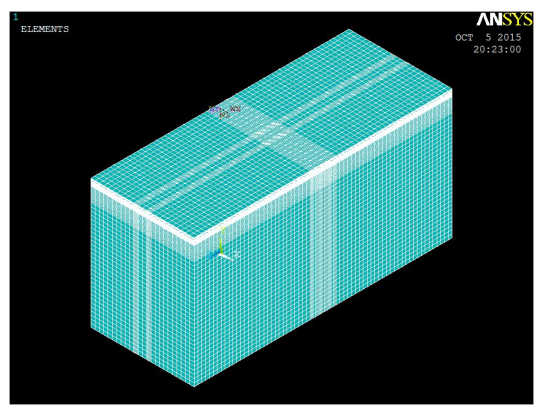

Figure 3. junction pavement in entrance and exit area

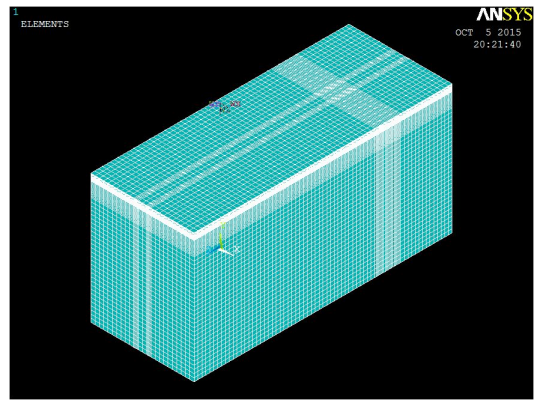

Figure 4. pavement in entrance and exit area in the tunnel

It was supposed that surface course materials were linear viscoelastic and other materials were homogeneous, isotropic and linear elastic ${ }^{[7]}$. The natural circular frequency of subgrade was $8.2 \mathrm{rad} / \mathrm{s}$, and other materials' were $18.6 \mathrm{rad} / \mathrm{s}^{[6]}$.

In this section, the speed varies. Vehicles accelerate when entering tunnels and decelerate when leaving tunnels. Thus in this paper, both vertical and horizontal loads were applied. Traffic loads would move $0.1 \mathrm{~m}$ in every load step and there were 9 load steps in each position.

Speed, acceleration ${ }^{[2]}$ and physico-mechanical calculation parameters of traffic loads were given in Table 3 and Table 4:

Table 3. Speed and acceleration of entrance and exit section

\begin{tabular}{|c|c|c|c|}
\hline \multicolumn{2}{|c|}{ Into tunnel } & \multicolumn{2}{c|}{ Out of tunnel } \\
\hline Speed & Acceleration & Speed & Acceleration \\
\hline $70 \mathrm{~km} / \mathrm{h}$ & $-0.16 \mathrm{~m} / \mathrm{s}^{-2}$ & $72 \mathrm{~km} / \mathrm{h}$ & $0.2 \mathrm{~m} / \mathrm{s}^{-2}$ \\
\hline
\end{tabular}


Table 4. physico-mechanical Calculation parameters of traffic loads

\begin{tabular}{|c|c|c|c|}
\hline $\begin{array}{c}\text { Standard axle } \\
\text { load P(KN) }\end{array}$ & 100 & Grounding shape & $\begin{array}{c}\text { Rectangle } \\
18 \mathrm{~cm} * 20 \mathrm{~cm}\end{array}$ \\
\hline $\begin{array}{c}\text { tire pressure } \\
\text { p(MPa) }\end{array}$ & 0.7 & $\begin{array}{c}\text { Distance between } \\
\text { centers of two } \\
\text { tires }(\mathrm{cm})\end{array}$ & 30 \\
\cline { 1 - 2 } $\begin{array}{c}\text { Friction } \\
\text { coefficient }\end{array}$ & 0.3 & \multicolumn{2}{|c}{} \\
\hline
\end{tabular}

\section{Simulation Results and Analysis}

\subsection{Critical stress chosen for entrance and exit section}

(1) Critical stress for tunnel pavement

Due to the large difference of dynamic modulus between asphalt mixtures and cement concrete, it was easy to fail in the interlayer. Thus, the maximum interlayer shear stress between asphalt concrete layer and cement concrete layer $\left(\tau_{\text {AC-PCC }}\right)$ was chosen for the pavement of tunnel.

\section{(2) Critical stress for main line pavement}

Due to the variation of speed and the consequent horizontal braking force, interlayer shear stress between SMA-13 and AC-16( $\left.\tau_{\text {SMA-AC }}\right)$, AC-16 and AC-20C $\left(\tau_{\text {AC-AC }}\right)$ in main line pavement were chosen.

\subsection{Results and analysis of $\tau_{\mathrm{AC}-\mathrm{PCC}}$}

To make a comparison between the pavement in entrance and exit area of the tunnel and regular one in the tunnel, the simulation results of $\tau_{\mathrm{AC}-\mathrm{PCC}}$ are shown in Table 5 .

Table 5. $\tau_{\mathrm{AC}-\mathrm{PCC}}$ in entrance and exit area of the tunnel and regular pavement in the tunnel

\begin{tabular}{|c|c|c|c|}
\hline \multirow[b]{2}{*}{ Load step } & Into tunnel & \multirow[b]{2}{*}{$\begin{array}{l}\text { Regular } \\
\text { pavement in } \\
\text { the } \\
\text { tunnel(MPa) }\end{array}$} & Out of tunnel \\
\hline & $\begin{array}{l}\text { pavement in } \\
\text { entrance and } \\
\text { exit area of } \\
\text { the } \\
\text { tunnel(MPa) }\end{array}$ & & $\begin{array}{l}\text { pavement in } \\
\text { entrance and } \\
\text { exit area of } \\
\text { the } \\
\text { tunnel(MPa) }\end{array}$ \\
\hline 1 & 0.2474 & 0.1810 & 0.2476 \\
\hline 2 & 0.2491 & 0.1959 & 0.2493 \\
\hline 3 & 0.2479 & 0.1941 & 0.2480 \\
\hline 4 & 0.2474 & 0.1940 & 0.2476 \\
\hline 5 & 0.2472 & 0.1941 & 0.2475 \\
\hline 6 & 0.2472 & 0.1941 & 0.2474 \\
\hline 7 & 0.2472 & 0.1942 & 0.2474 \\
\hline 8 & 0.2472 & 0.1942 & 0.2474 \\
\hline 9 & 0.2465 & 0.1937 & 0.2467 \\
\hline $\begin{array}{c}\text { Average } \\
\text { value }\end{array}$ & 0.2475 & 0.1928 & 0.2477 \\
\hline
\end{tabular}

From Table 5, it is shown that $\tau_{\mathrm{AC}-\mathrm{pCC}}$ in entrance and exit area of the tunnel is $28.37 \%$ larger than that of regular pavement in the tunnel, in both processes of entering and leaving tunnel.

It was probably because in the entrance and exit section the pavement geomaterials changed suddenly, therefore low cohesion between AC and PCC and inconsistent deformation of $\mathrm{AC}$ and $\mathrm{PCC}$ were caused. Besides, frequent acceleration and deceleration of moving loads may further deepen the difference. Thus $\tau_{\mathrm{AC}-\mathrm{PCC}}$ in entrance and exit area of tunnel increased.

When loads were applied on pavement in entrance and exit area of the main line and pavement in junction parts, the corresponding $\tau_{\mathrm{AC}-\mathrm{PCC}}$ in entrance and exit area of the tunnel was shown in Table 6 .

Table 6. $\tau_{\mathrm{AC}-\mathrm{PCC}}$ in entrance and exit area of tunnel when loads applied on pavement in entrance and exit area of the main line and pavement in junction parts

\begin{tabular}{|c|c|c|c|c|}
\hline \multirow{2}{*}{$\begin{array}{c}\text { Load } \\
\text { step }\end{array}$} & $\begin{array}{c}\text { Pavement } \\
\text { in entrance } \\
\text { and exit } \\
\text { area of the } \\
\text { main } \\
\text { line(MPa) }\end{array}$ & $\begin{array}{c}\text { Pavement } \\
\text { in entrance } \\
\text { and exit } \\
\text { area of the } \\
\text { junction } \\
\text { part(MPa) }\end{array}$ & $\begin{array}{c}\text { pavement } \\
\text { in entrance } \\
\text { and exit } \\
\text { area of the } \\
\text { main } \\
\text { line(MPa) }\end{array}$ & $\begin{array}{c}\text { Pavement } \\
\text { in entrance } \\
\text { and exit } \\
\text { area of the } \\
\text { junction } \\
\text { part(MPa) }\end{array}$ \\
\hline 1 & 0.0076 & 0.0708 & 0.0261 & 0.2461 \\
\hline 2 & 0.0208 & 0.1022 & 0.0259 & 0.2484 \\
\hline 3 & 0.0340 & 0.1513 & 0.0255 & 0.2519 \\
\hline 4 & 0.0456 & 0.2641 & 0.0250 & 0.2505 \\
\hline 5 & 0.0556 & 0.2968 & 0.0243 & 0.2687 \\
\hline 6 & 0.0640 & 0.2495 & 0.0231 & 0.2995 \\
\hline 7 & 0.0708 & 0.2387 & 0.0208 & 0.2185 \\
\hline 8 & 0.0760 & 0.2424 & 0.0160 & 0.1549 \\
\hline 9 & 0.0796 & 0.2444 & 0.0079 & 0.1163 \\
\hline
\end{tabular}

It is found that in the process of entering tunnel, $\tau_{\text {AC-PCC }}$ increases with loads moving forward and peaks when loads arrive just at the junction position of two pavement structures. After that it decreases to the value of the pavement in entrance and exit area of the tunnel (shown in Figure 5), and vice versa in the process of going out of tunnel(shown in Figure 6). But the maximum of $\tau_{\mathrm{AC}-\mathrm{PCC}}$ during the processes of going into and out of tunnel are $19.92 \%$ and $20.91 \%$ larger than the average value of $\tau_{\mathrm{AC}-\mathrm{PCC}}$ in entrance and exit area of the tunnel respectively, which may be also caused by the suddenly changing geomaterials.

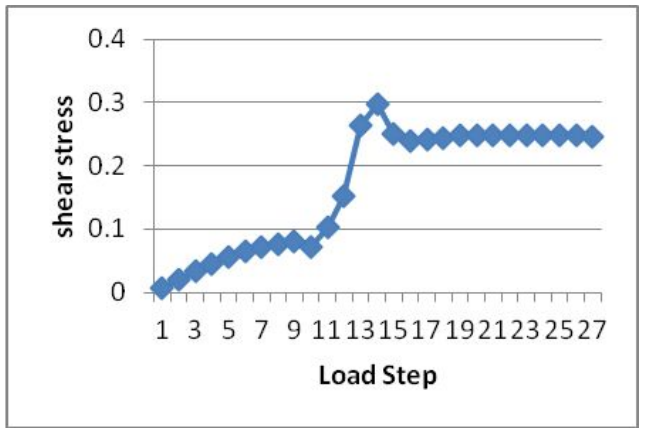

Figure 5. The variation of $\tau_{\mathrm{AC}-\mathrm{PCC}}$ in the process of entering tunnel 


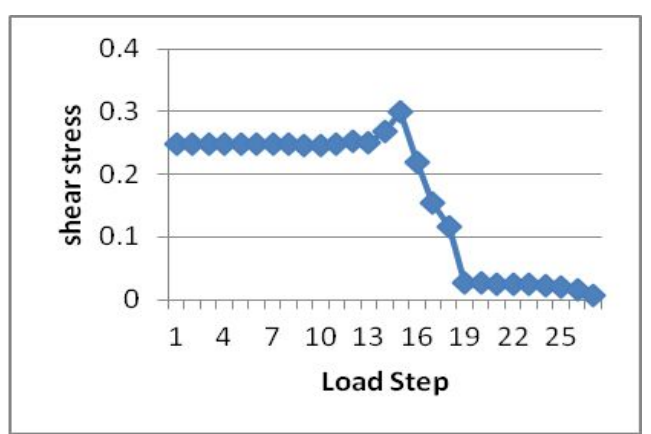

Figure 6. The variation of $\tau_{\mathrm{AC}-\mathrm{PCC}}$ in the process of leaving tunnel

\subsection{Results and analysis of $\tau_{\mathrm{SMA}-\mathrm{AC}}$}

The simulation results of $\tau_{\text {SMA-AC }}$ in the entrance and exit area of the main line and regular main line pavement are listed in Table 7.

Table 7. $\tau_{\text {SMA-AC }}$ in the entrance and exit area of the main line and regular main line pavement

\begin{tabular}{|c|c|c|c|}
\hline \multirow[b]{2}{*}{ Load step } & Into tunnel & \multirow[b]{2}{*}{$\begin{array}{c}\text { Regular main } \\
\text { line } \\
\text { pavement } \\
(\mathrm{MPa})\end{array}$} & Out of tunnel \\
\hline & $\begin{array}{l}\text { pavement in } \\
\text { entrance and } \\
\text { exit area of } \\
\text { the main } \\
\text { line }(\mathrm{MPa})\end{array}$ & & $\begin{array}{l}\text { pavement in } \\
\text { entrance and } \\
\text { exit area of } \\
\text { the main } \\
\text { line }(\mathrm{MPa})\end{array}$ \\
\hline 1 & 0.1420 & 0.1419 & 0.1395 \\
\hline 2 & 0.1862 & 0.1863 & 0.1837 \\
\hline 3 & 0.1792 & 0.1798 & 0.1763 \\
\hline 4 & 0.1775 & 0.1787 & 0.1748 \\
\hline 5 & 0.1769 & 0.1785 & 0.1744 \\
\hline 6 & 0.1767 & 0.1786 & 0.1743 \\
\hline 7 & 0.1768 & 0.1788 & 0.1742 \\
\hline 8 & 0.1771 & 0.1789 & 0.1740 \\
\hline 9 & 0.1773 & 0.1786 & 0.1737 \\
\hline $\begin{array}{l}\text { Average } \\
\text { value }\end{array}$ & 0.1744 & 0.1756 & 0.1717 \\
\hline
\end{tabular}

From Table 7, it is shown that there is minor difference between $\tau_{\mathrm{SMA}-\mathrm{AC}}$ of regular main line pavement and that in entrance and exit area of main line in both processes. The average $\tau_{\text {SMA-AC }}$ value of regular main line pavement are the biggest in the three, which is $0.69 \%$ higher than that in the process of going into tunnel and $2.27 \%$ higher than that in the process of going out of tunnel.

$\tau_{\text {SMA-AC }}$ in entrance and exit area of main line is quite small when loads were applied on pavement in entrance and exit area in the tunnel and decreases with the increase of distance away from the pavement in entrance and exit area of main line in both process(shown in Table 8). It should also be taken notice that in this situation $\tau_{\text {SMA-AC }}$ in the process of going out of tunnel is almost $4 \sim 5$ times of that in the other process. When loads were applied on junction parts, $\tau_{\text {SMA-AC }}$ increases and peaks at the junction position both in the processes of going into and leaving tunnel, but their maxima are quite different, with the former $32.24 \%$ higher than the latter.
Table 8. $\tau_{\text {SMA-AC }}$ in entrance and exit area of main line when loads applied on pavement in entrance and exit area of the tunnel and pavement in junction parts

\begin{tabular}{|c|c|c|c|c|}
\hline \multirow{2}{*}{$\begin{array}{c}\text { Load } \\
\text { step }\end{array}$} & $\begin{array}{c}\text { Pavement } \\
\text { in } \\
\text { entrance } \\
\text { and exit } \\
\text { area of the } \\
\text { junction } \\
\text { part(MPa) }\end{array}$ & $\begin{array}{c}\text { Pavement in } \\
\text { entrance and } \\
\text { exit area of } \\
\text { the } \\
\text { tunnel(MPa) }\end{array}$ & $\begin{array}{c}\text { Pavement in } \\
\text { entrance and } \\
\text { exit area of } \\
\text { the } \\
\text { tunnel(MPa) }\end{array}$ & $\begin{array}{c}\text { Pavement } \\
\text { in } \\
\text { entrance } \\
\text { and exit } \\
\text { area of the } \\
\text { junction } \\
\text { part(MPa) }\end{array}$ \\
\hline 1 & 0.1529 & 0.000070 & 0.000210 & 0.0040 \\
\hline 2 & 0.2132 & 0.000055 & 0.000223 & 0.0073 \\
\hline 3 & 0.2220 & 0.000050 & 0.000232 & 0.0159 \\
\hline 4 & 0.2748 & 0.000055 & 0.000241 & 0.0859 \\
\hline 5 & 0.3060 & 0.000055 & 0.000251 & 0.1620 \\
\hline 6 & 0.1558 & 0.000052 & 0.000263 & 0.2314 \\
\hline 7 & 0.0638 & 0.000047 & 0.000276 & 0.2184 \\
\hline 8 & 0.0244 & 0.000040 & 0.000291 & 0.2087 \\
\hline 9 & 0.0120 & 0.000033 & 0.000308 & 0.2003 \\
\hline
\end{tabular}

\subsection{Results and analysis of ${ }^{\tau_{A C}-A C}$}

$\tau_{\mathrm{AC}-\mathrm{AC}}$ in the entrance and exit area of the main line and regular main line pavement are shown in Table 9.

Table 9. $\tau_{\mathrm{AC}-\mathrm{AC}}$ in the entrance and exit area of the main line and regular main line pavement

\begin{tabular}{|c|c|c|c|}
\hline \multirow[b]{2}{*}{ Load step } & Into tunnel & \multirow[b]{2}{*}{$\begin{array}{c}\text { Regular } \\
\text { main line } \\
\text { pavement } \\
(\mathrm{MPa})\end{array}$} & Out of tunnel \\
\hline & $\begin{array}{l}\text { pavement in } \\
\text { entrance and } \\
\text { exit area of the } \\
\text { main line }(\mathrm{MPa})\end{array}$ & & $\begin{array}{l}\text { pavement in } \\
\text { entrance and exit } \\
\text { area of the main } \\
\text { line(MPa) }\end{array}$ \\
\hline 1 & 0.1129 & 0.1128 & 0.1109 \\
\hline 2 & 0.1457 & 0.1457 & 0.1435 \\
\hline 3 & 0.1437 & 0.1441 & 0.1415 \\
\hline 4 & 0.1423 & 0.1432 & 0.1404 \\
\hline 5 & 0.1417 & 0.1430 & 0.1400 \\
\hline 6 & 0.1415 & 0.1430 & 0.1399 \\
\hline 7 & 0.1416 & 0.1431 & 0.1398 \\
\hline 8 & 0.1417 & 0.1431 & 0.1397 \\
\hline 9 & 0.1417 & 0.1428 & 0.1392 \\
\hline $\begin{array}{c}\text { Average } \\
\text { value }\end{array}$ & 0.1392 & 0.1401 & 0.1372 \\
\hline
\end{tabular}

From Table 9, it could be found that $\tau_{\mathrm{AC}-\mathrm{AC}}$ of regular main line pavement is slightly different from that in the entrance and exit area of the main line. In this situation, the values of $\tau_{\mathrm{AC}-\mathrm{AC}}$ are smaller than $\tau_{\mathrm{SMA}-\mathrm{AC}}$ as a whole.

However, it is quite different when loads were applied on the pavement in entrance and exit area of the tunnel that $\tau_{\mathrm{AC}-\mathrm{AC}}$ are almost 4 times of $\tau_{\mathrm{SMA}-\mathrm{AC}}$ (shown in Table 10). Because the values of $\tau_{\mathrm{AC}-\mathrm{AC}}$ are small, its effect on pavement would probably be small. When loads were applied on junction pavement, $\tau_{\mathrm{AC}-\mathrm{AC}}$ increases and also peaks just at the junction position. The maxima of $\tau_{\mathrm{AC}-\mathrm{AC}}$ in both process are nearly same, with difference of $0.91 \%$, which is quite different from $\tau_{\text {SMA-AC. }}$ 
Table 10. $\tau_{\mathrm{AC}-\mathrm{AC}}$ in entrance and exit area of main line when loads applied on pavement in entrance and exit area of the tunnel and pavement in junction parts

\begin{tabular}{|c|c|c|c|c|}
\hline \multirow{2}{*}{$\begin{array}{c}\text { Load } \\
\text { step }\end{array}$} & $\begin{array}{c}\text { Pavement } \\
\text { in } \\
\text { entrance } \\
\text { and exit } \\
\text { area of the } \\
\text { junction } \\
\text { part(MPa) }\end{array}$ & $\begin{array}{c}\text { Pavement in } \\
\text { entrance and } \\
\text { exit area of } \\
\text { the } \\
\text { tunnel(MPa) }\end{array}$ & $\begin{array}{c}\text { Pavement in } \\
\text { entrance and } \\
\text { exit area of } \\
\text { the } \\
\text { tunnel(MPa) }\end{array}$ & $\begin{array}{c}\text { Pavement } \\
\text { in } \\
\text { entrance } \\
\text { and exit } \\
\text { area of the } \\
\text { junction } \\
\text { part(MPa) }\end{array}$ \\
\hline 1 & 0.1224 & 0.000232 & 0.000895 & 0.0115 \\
\hline 2 & 0.1645 & 0.000179 & 0.000961 & 0.0173 \\
\hline 3 & 0.1869 & 0.000210 & 0.001002 & 0.0319 \\
\hline 4 & 0.2641 & 0.000228 & 0.001046 & 0.0982 \\
\hline 5 & 0.2968 & 0.000223 & 0.001094 & 0.2583 \\
\hline 6 & 0.1609 & 0.000207 & 0.001155 & 0.2995 \\
\hline 7 & 0.0503 & 0.000183 & 0.001237 & 0.2185 \\
\hline 8 & 0.0330 & 0.000158 & 0.001331 & 0.1783 \\
\hline 9 & 0.0212 & 0.000131 & 0.001440 & 0.1674 \\
\hline
\end{tabular}

\section{Conclusion}

In this paper, the 3-D FE model of the pavement structure in entrance and exit section was established considering viscoelastic property of asphalt mixture and the damping effect of the structure. Three chosen stress indexes were calculated under moving loads:

(1) $\tau_{\mathrm{AC}-\mathrm{AC}}$ in the entrance and exit area of tunnel is larger than that of regular pavement in the tunnel. It is probably because geomaterials suddenly changed in this area, therefore low cohesion between $\mathrm{AC}$ and PCC and inconsistent deformation of AC and PCC was caused. Besides, frequent acceleration and deceleration of moving loads further deepened the difference of $\tau_{\mathrm{AC}-\mathrm{AC}}$ between pavement in the entrance and exit area of tunnel and regular pavement in the tunnel.

(2) $\tau_{\text {SMA-AC }}$ of regular main line pavement and the entrance and exit area of main line are nearly all the same. When loads were applied on entrance and exit area of the tunnel, $\tau_{\mathrm{SMA}-\mathrm{AC}}$ in the process of leaving tunnel is almost $4 \sim 5$ times of that in the other process. When loads were applied on junction pavement in entrance and exit area, maxima of $\tau_{\mathrm{SMA}-\mathrm{AC}}$ in two processes are quite different and that in the process of going into tunnels is $32.24 \%$ higher than the other.

(3) when loads were applied on the entrance and exit area of tunnel, values of $\tau_{\mathrm{AC}-\mathrm{AC}}$ are almost 4 times of that of $\tau_{\text {SMA-AC }}$. However, $\tau_{\mathrm{AC}-\mathrm{AC}}$ is lower than $\tau_{\mathrm{SMA}-\mathrm{AC}}$ when loads were applied on the pavement in entrance and exit area of main line and regular main line pavement.

\section{References}

[1] Gao J., Research on Pavement Structures and Materials in import and export of Highway tunnel Based on the safety (2012)

[2] Fang J., Wang S., Zhu Z., Zhou G., Journal of Traffic and Transportation Engineering,10, 90 (2010)

[3] Li Y., The Pavement Type Selection And Structure Design Research Of Laoshan Tunnel (2005)
[4] Ma X., Guo Z., Li Z., Yang Q., China Journal of Highway and Transport, 22, 34 (2009)

[5] Zhuang C., Structural Design Indexes and Parameters for Flexible Base Asphalt Pavement based on Accelerated Pavement Testing(2012)

[6] Liao Gongming, Huang Xiaoming. Application of ABAQUES Finite Element Software in Road Engineering(Southeast University Press,2008)

[7] Cao W., Lü P., Journal of Jiangsu University: Natural and Science Edition, 35, 444 (2014)

[8] Zheng J., Journal of Changsha Communications institute, 11, 32 (1995) 